\title{
MEKANISME LEGISLATIVE REVIEW PERATURAN PEMERINTAH PENGGANTI UNDANG-UNDANG DALAM PERSPEKTIF POLITIK HUKUM
}

\author{
Muhammad Fadli Efendi \\ Program Magister Ilmu Hukum, Fakultas Hukum Universitas Brawijaya \\ email: fadliefendi@student.ub.ac.id
}

disampaikan 07/09/2020 - di-review 15/10/2020 - diterima 16/11/2021

DOI: $10.25123 /$ vej.v7i2.4215

\begin{abstract}
With the issuance of Constitutional Court decision No. 138/PUU-VII/2009, a legal conflict arises between the Parliament and Constitutional Court, regarding which state institution possess the authority to review any Government Regulation in lieu of Law. Both institutions declared themselves to be having the sole authority to do just that. The author, using a juridical normative approach, suggest otherwise. In the auhtor's opinion, it is the Parliament who should be regarded as having the sole authority. This said taking into consideration that - as soon as the emergency justifung the issuance of the government regulation in lieu of legislation ends - both the government and the parliament shall as soon as possible convene to determine whether this government regulation should be declared null and void or elevated to the status of Law.
\end{abstract}

Keyword:

Legislative Review; Constitutional Court; Government Regulation in lieu of Legislation; Parliament;

\begin{abstract}
Abstrak
Sejak adanya putusan MK Nomor 138/PUU-VII/2009, ditengarai adanya konflik kewenangan pengujian PERPPU antara Mahkamah Konstitusi dengan DPR. Keduanya menyatakan diri wenang menguji PERPPU. Di dalam tulisan ini akan diajukan argumentasi, berdasarkan pendekatan yuridis normative, bahwa kewenangan melakukan pengujian terhadap PERPPU, seyogianya ada pada DPR, satu dan lain, mengingat adanya kewajiban DPR dan Pemerintah untuk - segera setelah keadaan darurat berakhir dan situasi kembali normal - mengadakan sidang untuk membahas PERPPU dan memilih untuk menyetujui PERPPU dan menjadikannya Undang-Undang atau menolaknya
\end{abstract}

Kata Kunci:

Legislative Review; Mahkamah Konstitusi; PERPPU; DPR;

\section{Pendahuluan}

Dalam sebuah kehidupan manusia selalu dikelilingi dengan adanya hukum yang mengatur pola perilaku setiap manusia dimuka bumi. Sebagaimana ungkapan dalam buku yang berjudul "Legislative Drafting: Pelembagaan Metode Partisipatif Dalam Pembentukan Peraturan Perundang-undangan" Hukum itu bagaikan udara bagi hidup manusia, hewan, dan tumbuh-tumbuhan. ${ }^{1}$ Sehingga tidak asing lagi dengan pernyataan dimana ada masyarakat disitu ada hukum.

1 Sirajuddin, dkk, Legislative Drafting: Pelembagaan Metode Partisipatif Dalam Pembentukan Peraturan Perundang-Undangan, Setara Press, Malang, 2016, hlm., 1 
Hukum bertujuan untuk menciptakan keadilan, kemanfaatan, dan kepastian dalam tatanan kehidupan berbangsa dan bernegara. Konsep tiga tujuan hukum ini diperkenalkan oleh Gustav Radbruch dengan menggunakan asas prioritas. $^{2}$ Dalam teori tujuan hukum barat ini mencakup 2 teori yaitu (1) teori prioritas baku yang terdiri atas keadilan, kemanfaatan, kepastian; (2) teori prioritas kasuistik merupakan tujuan hukum dengan urutan prioritas secara proporsional sesuai dengan kasus yang dihadapi dan ingin dipecahkan. ${ }^{3}$ Dari kedua teori ini menggambarkan bahwa kaitannya dengan hukum yang dibentuk haruslah mencerminkan nilai-nilai hukum yang dapat memberikan keadilan, kemanfataan, dan kepastian, sewalaupun itu menggunakan urutan prioritas yang secara proporsional.

Berbicara mengenai hukum tidak terlepas dari yang namanya politik, bahkan pernyataan hukum adalah produk politik bisa benar jika didasarkan pada das sein dengan mengonsepkan hukum sebagai Undang-Undang, itulah sebabnya Von Kirchman mengatakan bahwa karena hukum merupakan produk politik maka kepustakaan hukum yang ribuan jumlahnya bisa menjadi sampah yang tak berguna jika lembaga legislatif mengetokkan palu pencabutan atau pembatalannya. ${ }^{4}$ Sehingga Mahfud MD berpendapat bahwa politik hukum adalah “Legal policy garis (kebijakan) resmi tentang hukum yang akan diberlakukan baik dengan pembuatan hukum baru maupun dengan penggantian hukum lama, dalam rangka mencapai tujuan Negara. ${ }^{5}$

Negara Indonesia adalah Negara hukum sebagaimana dinyatakan secara tegas dalam Pasal 1 ayat (3) UUD NRI 1945, bahkan dalam pembukaan UUD NRI 1945 tersirat suatu makna, bahwa Negara Republik Indonesia yang berdiri pada tanggal 17 Agustus 1945 adalah Negara yang berdasar atas hukum (Rechtsstaat) dalam arti negara pengurus (Verzorgingsstaat). ${ }^{6}$

Id.

3 Achmad Ali, Menguak Teori Hukum (Legal Theory) Dan Teori Peradilan (Judicialprudence): Termasuk Interpretasi Undang-Undang (Legisprudence), Kencana, Jakarta, 2017, hlm., 171

4 Moh. Mahfud MD, Politik Hukum Di Indonesia, Rajawali Press, Jakarta, 2011, hlm., 5 Id.

6 Maria Farida Indrati S., Ilmu Perundang-Undangan 1, Kanisius, Yogyakarta, 2007, hlm., 1 
Sebagaimana Maria Farida menjelaskan bahwa:

"Dengan diembannya tugas Negara dalam menyelenggarakan kesejahteraan umum, maka pembentukan berbagai peraturan di Negara Republik Indonesia menjadi sangat penting, oleh karena campur tangan Negara dalam mengurusi kesejahteraan rakyat dalam bidang hukum, sosial, politik, ekonomi, budaya, lingkungan hidup, serta pertahanan dan keamanan yang diselenggarakan dengan pembentukan peraturanperaturan negara tak mungkin lagi dihindarkan."7

Peraturan Perundang-undangan di Republik Indonesia begitu banyak dan beraneka ragam bentuknya, sebagaimana termaktub pada Pasal 7 ayat (1) Undang-Undang RI No. 12 Tahun 2011 tentang Pembentukan Peraturan Perundang-undangan sebagaimana telah diubah dengan Undang-Undang RI No. 15 Tahun 2019 tentang Perubahan atas Undang-Undang No. 12 Tahun 2011 tentang Pembentukan Peraturan Perundang-undangan yang berbunyi: Jenis dan hierarki Peraturan Perundang-undangan terdiri atas; UUD NRI 1945, TAP MPR, UU/PERPPU, PP, PERPRES, PERDA Prov, dan PERDA Kab/Kota. Selain jenis dan hierarki Peraturan Perundang-undangan di atas juga terdapat beberapa peraturan perundang-undangan lainnya yang juga memiliki kekuatan hukum mengikat. ${ }^{8}$

Peraturan Pemerintah Pengganti Undang-Undang (PERPPU) merupakan peraturan perundang-undangan khusus yang latar belakang pembentukannya hingga pengujiannya memiliki mekanisme perlakuan khusus pula (extra ordinary order). Dalam hal pengujiannya, Lutfil Anshori sependapat bahwa pengujian PERPPU ada pada DPR (dalam artian Legislative Review). Peraturan Pemerintah Pengganti Undang-Undang (PERPPU) bukanlah Undang-Undang selagi bernama PERPPU maka pengujiannya tidak dapat disamakan dengan Undang-Undang, kecuali jika PERPPU tersebut telah disidangkan oleh DPR dan mendapat persetujuan menjadi Undang-Undang. ${ }^{9}$ Ketika PERPPU tersebut disetujui menjadi Undang-Undang, maka pengujian Undang-Undang terhadap Undang-Undang

Id.

8 Undang-Undang R.I., No. 12 Tahun 2011, Pembentukan Peraturan Perundang-undangan, L.N.R.I. Tahun 2011 No. 82, Pasal 8 ayat (1).

9 Erlangga Hamid Putra Zakaria, Legislative Review Dewan Perwakilan Rakyat Terhadap Peraturan Pemerintah Pengganti Undang-Undang, Vol. VII, No. 1, LEX ADMINISTRATUM, hlm 62-63, 2019. 
Dasar disebut dengan Judicial Review dilakukan oleh Mahkamah Konstitusi yang telah menjadi kewenangannya sebagaimana amanah konstitusi di Indonesia.

Sama halnya Ni'matul Huda berpendapat bahwa yang berwenang menguji Peraturan Pemerintah Pengganti Undang-Undang adalah DPR, adanya kebutuhan dalam praktek untuk menguji Peraturan Pemerintah Pengganti Undang-Undang oleh Mahkamah Konstitusi seharusnya menjadi kajian serius bagi MPR dalam menentukan perlu tidaknya mengubah Undang-Undang Dasar Negara Republik Indonesia Tahun $1945 .^{10}$

Istilah pengujian peraturan perundang-undangan dapat dibagi berdasarkan subyek yang melakukan pengujian, obyek peraturan yang diuji, dan waktu pengujian. Dilihat dari segi subyek yang melakukan pengujian, pengujian dapat dilakukan oleh hakim (toetsingsrecht van de rechter atau judicial review), pengujian oleh lembaga legislatif (legislative review), maupun pengujian oleh lembaga eksekutif (executive review). ${ }^{11}$

Dalam hal pengujian Peraturan Pemerintah Pengganti Undang-Undang (PERPPU) hingga saat ini masih menjadi polemik dan perbincangan hangat di dunia akademis, dimana Mahkamah Konstitusi menyatakan berwenang untuk menguji Peraturan Pemerintah Pengganti Undang-Undang (PERPPU) sebagaimana bunyi dari pertimbangan hukum dalam Putusan MK Nomor 138/PUU-VII/2009 tentang Permohonan Pengujian Peraturan Pemerintah Pengganti Undang-Undang No. 4 Tahun 2009 tentang Perubahan Atas Undang-Undang No. 30 Tahun 2002 tentang Komisi Pemberantasan Tindak Pidana Korupsi terhadap Undang-Undang Dasar Negara Republik Indonesia Tahun 1945.

Padahal secara konstitusional sebagaimana termaktub pada Pasal 24C ayat (1) Undang-Undang Dasar Negara Republik Indonesia Tahun 1945 menyatakan bahwa: Mahkamah Konstitusi berwenang mengadili pada tingkat pertama dan terakhir yang putusannya bersifat final untuk menguji Undang-Undang terhadap

10 Ni'matul Huda, Dinamika Ketatanegaraan Indonesia Dalam Putusan MK, FH UII Press, Yogyakarta, 2011, hlm., 24

11 Ali Safa'at, Toetsingsrecht Van De Rechter, Hukum Acara Pengujian Undang-Undang Terhadap Undang-Undang Dasar, hlm 82-148, 2006, http://safaat.lecture.ub.ac.id/files/2011/11/BABV_PUU.pdf, diakses 20 Agusutus, 2020. 
Undang-Undang Dasar, memutus sengketa kewenangan lembaga negara yang kewenangannya diberikan oleh Undang-Undang Dasar, memutus pembubaran partai politik dan memutus perselisihan tentang hasil pemilihan umum.

Sehingga dari latar belakang diatas, maka penulis tertarik untuk mengulas lebih khusus dan komprehensif mengenai Legislative Review terhadap Peraturan Pemerintah Pengganti Undang-Undang (PERPPU) dilihat dari perspektif politik hukum, mulai dari proses pembentukannya hingga pada mekanisme Legislative Review terhadap Peraturan Pemerintah Pengganti Undang-Undang (PERPPU).

Dalam penelitian ini penulis menggunakan metode pendekatan perundangundangan (Statute Approach), karena yang diteliti adalah berbagai aturan hukum yang menjadi fokus dan tema sentral suatu penelitian dengan melihat hukum sebagai sistem tertutup yang mempunyai sifat-sifat comprehensive, all-inclusive, and systematic. ${ }^{12}$ Sebagaimana juga dikemukakan oleh Peter Mahmud Marzuki bahwa "Pendekatan Undang-undang (Statute Approach) dilakukan dengan menelaah semua undang-undang dan regulasi yang bersangkut paut dengan isu hukum yang sedang ditangani."13 Selain itu penulis juga menggunakan metode pendekatan konseptual (Conceptual Approach), pendekatan konseptual (Conceptual Approach) merupakan jenis pendekatan dalam penelitian hukum yang memberikan sudut pandang analisa penyelesaian permasalahan dalam penelitian hukum dilihat dari aspek konsep-konsep hukum yang melatarbelakangi, yang beranjak dari pandangan-pandangan dan doktrin-doktrin yang berkembang di dalam ilmu hukum. ${ }^{14}$ Adapun jenis penelitian yang digunakan adalah penelitian yuridis normatif yang menitikfokuskan pada norma hukum positif. Sebagaimana disampaikan oleh I Made Pasek Dhianta bahwa "Hukum normatif itu yang meneliti hukum dari perspektif internal dengan obyek penelitiannya adalah norma hokum" ${ }^{15}$

12 Jonaedi Efendi dan Johnny Ibrahim, Metode Penelitian Hukum Normatif Dan Empiris, Prenadamedia Group, Depok, 2018, hlm., 132

13 Peter Mahmud Marzuki, Penelitian Hukum, Kencana, Jakarta, 2017, hlm., 133

14 Ani Purwati, Metode Penelitian Hukum Teori Dan Praktek, ed. Tika Lestari, Jakad Media Publishing, Surabaya, 2020, hlm., 88-89

15 I Made Pasek Dhianta, Metode Penelitian Hukum Normatif; Dalam Justifikasi Teori Hukum, Kencana, Jakarta, 2016, hlm., 12 


\section{Pembahasan}

\section{Kedudukan PERPPU Dalam Jenjang Norma Hukum}

Peraturan hukum keseluruhannya diturunkan dari norma dasar yang berada di puncak piramida, dan semakin ke bawah semakin beragam dan menyebar. Norma dasar teratas adalah bersifat abstrak dan semakin ke bawah semakin konkret. Inilah ajaran dari Hans Kelsen yang disebut dengan ajaran tentang Stufenbautheorie. ${ }^{16}$

Hans Kelsen berpendapat bahwa norma-norma hukum itu berjenjangjenjang dan berlapis-lapis dalam suatu hierarki tata susunan, dimana suatu norma yang lebih rendah berlaku, bersumber, dan berdasar pada norma yang lebih tinggi lagi, demikian seterusnya norma yang tidak dapat ditelesuri lebih lanjut dan bersifat hipotesis dan fiktif, yaitu norma dasar (grundnorm). ${ }^{17}$ Mengapa grundnorm tidak dapat ditelusuri lebih lanjut? Karena, Kelsen tidak ingin hierarki hukum yang tertinggi (konstitusi) disandarkan pada suatu yang metayuridis. Norma dasar ini merupakan norma tertinggi dalam sistem norma tersebut, tidak lagi dibentuk oleh suatu norma yang lebih tinggi lagi tetapi norma itu ditetapkan terlebih dahulu oleh masyarakat sebagai norma dasar yang merupakan gantungan bagi norma yang berada dibawahnya. ${ }^{18}$

Bahkan menurut J.H. M. Klanderman, dari pikiran Hans Kelsen itu menyatakan "de Grundnorm niet een rechtsnorm maar gedachte norm" (Grundnorm itu bukanlah norma hukum, akan tetapi adalah norma pikiran). ${ }^{19}$ I Gede Pantja Astawa berpendapat bahwa norma dasar yang dimaksudkan oleh Merkl tidak sama dengan Grundnorm yang dikembangkan oleh Hans Kelsen. Letak perbedaannya adalah kalau norma dasar yang dimaksud Merkl sebagai tempat bergantungnya norma-norma dibawahnya itu adalah kerangka berpikir untuk teori jenjang norma hukum, ia memang dapat diubah (seperti amandemen UUD sebagai norma hukum tertinggi), sedangkan Grundnorm menurut Hans Kelsen itu

Achmad Ali, supra no. 3, hlm 50

Sirajuddin, dkk, supra no. 1, hlm 42

Id.

19 I Dewa Gede Atmadja dan I Nyoman Putu Budiartha, Teori-Teori Hukum, Setara Press, Malang, 2018, hlm., 151 
adalah sesuatu yang abstrak, diasumsikan tidak tertulis dan berlaku secara universal. Ia menjadi landasan segala sumber hukum dalam arti formal dan ia meta-juristic sifatnya. ${ }^{20}$

Sedangkan menurut Munir Fuady dalam bukunya yang berjudul "TeoriTeori Besar (Grand Theory) Dalam Hukum" menyampaikan bahwa grundnorm (norma dasar) adalah kaidah-kaidah yang paling fundamental tentang kehidupan manusia dimana atas norma dasar tersebut dibuatlah kaidah-kaidah hukum lain yang lebih konkret dan lebih khusus. Biasanya, norma dasar berlaku dalam suatu Negara ditulis dalam konstitusi dari Negara tersebut. Suatu norma dasar tidak dengan sendirinya mengikat secara hukum tanpa kehadiran suatu aturan hukum pada tataran yang lebih konkret berupa norma hukum yang valid. ${ }^{21}$ Lebih lanjut Munir Fuady berpendapat bahwa sesuai dengan teorinya Hans Kelsen, maka setiap hukum dalam suatu negara haruslah berasal dari suatu hukum dasar (grundnorm) yaitu konstitusi. Karena itu, untuk mengukur konsistensinya dengan hukum dasar, berkembanglah beberapa kaidah hukum tentang logika ilmu hukum, yaitu: 22

1. Kaidah derogasi, dalam hal ini, setiap aturan hukum berasal dari aturan hukum yang lebih tinggi.

2. Kaidah pengakuan (recognition), setiap kaidah hukum yang berlaku harus ada pengakuan dari yang berwenang menjalankan aturan tersebut, maupun pengakuan dari pihak kepada siapa aturan hukum tersebut akan ditetapkan.

3. Kaidah nonkontradiksi, tidak boleh ada kontradiksi antara satu aturan hukum dengan aturan hukum lainnya, sehingga antara satu norma hukum dengan norma hukum lainnya haruslah harmonis, sinkron, dan terintegrasi (principle of integrity).

20 I Gde Pantja Astawa, Dinamika Hukum dan Ilmu Perundang-undangan di Indonesia, PT Alumni, Bandung, 2008, hlm., 37

21 Munir Fuady, Teori-Teori Besar (Grand Theory) Dalam Hukum, Kencana, Jakarta, 2014, hlm., 138

22 Id. 
4. Kaidah derivatif (derivative principle), dalam hal ini, aturan hukum di tingkat bawah merupakan bagian dari aturan hukum tingkat lebih tinggi yang ditarik berdasarkan prinsip deduksi pratikal.

5. Kaidah sistem (systemic principle), dalam hal ini, suatu sistem hukum yang lebih rendah tingkatannya merupakan sub sistem dari peraturan hukum yang lebih tinggi, sehingga semua aturan hukum yang berlaku merupakan sebuah sistem secara keseluruhan.

6. Kaidah generalisasi (generalized principle), dalam hal ini, aturan hukum yang lebih tinggi merupakan generalisasi dari aturan hukum yang lebih rendah. Demikian juga sebaliknya, bahwa aturan yang lebih rendah merupakan kekhusussan dari aturan yang lebih tinggi.

7. Kaidah reduksi (principle of reductionism), dimana aturan hukum yang lebih rendah merupakan reduksi dari aturan yang lebih tinggi.

8. Kaidah golongan ketercakupan (principle of subsumption), dalam arti bahwa aturan hukum harus masih termasuk atua tercakup ke dalam golongan aturan yang lebih tinggi. Jadi, bukan berasal dari golongan aturan yang lain.

Masih menurut Kelsen, hukum merupakan norma yang dinamik, dimana hukum merupakan sesuatu yang dibuat berupa suatu prosedur tertentu dan segala sesuatu yang dibuat melalui cara ini adalah hukum. ${ }^{23}$ Kemudian salah seorang murid Kelsen bernama Hans Nawiasky mengembangkan teori yang dikedepankan Kelsen. Nawiasky berpendapat bahwa selain norma itu berlapislapis dan berjenjang-jenjang, norma hukum dari suatu negara itu juga berkelompok-kelompok. Nawiasky mengelompokkan norma-norma hukum dalam suatu negara itu menjadi 4 (empat) kelompok besar yang terdiri dari: (1) staatfundamentalnorm (norma fundamental negara), (2) staatgrundgesetz (aturan dasar/pokok negara), (3) formal Gesetz (Undang-undang formal), (4) Verordnung and Autonome Satzung (aturan pelaksana dan aturan otonom). ${ }^{24}$

Sama halnya peraturan hukum positif di negara Indonesia sebenarnya juga berjenjang-jenjang dan berlapis-lapis sebagaimana bisa dilihat pada UU Nomor 12

23 Sirajuddin, dkk, supra no 17 , hlm., 42 24 Id. 
Tahun 2011 tentang Pembentukkan Peraturan Perundang-undangan sebagaimana telah diubah dengan UU No. 15 Tahun 2019 tentang Perubahan atas UU No. 12 Tahun 2011.

Peraturan Pemerintah Pengganti Undang-Undang (PERPPU) merupakan norma hukum yang lahir berdasarkan ketentuan konstitusional dalam Pasal 22 UUD NRI 1945 yang menyatakan:

(1) Dalam hal-ihwal kegentingan yang memaksa, Presiden berhak menetapkan peraturan pemerintah sebagai pengganti undang-undang;

(2) Peraturan pemerintah itu harus mendapat persetujuan Dewan Perwakilan Rakyat dalam persidangan yang berikut;

(3) Jika tidak mendapat persetujuan, maka peraturan pemerintah itu harus dicabut.

Dari ketentuan diatas maka PERPPU merupakan bentuk peraturan perundang-undangan yang ditetapkan oleh Presiden tanpa didahului oleh persetujuan DPR. Hak Presiden untuk menetapkan PERPPU hanya dapat dilakukan dan dilaksanakan dalam hal-ikhwal kegentingan memaksa. Dalam keadaan kembali normal maka PERPPU harus dibicarakan kembali dengan DPR dengan kemungkinan disetujui menjadi UU dan kalau tidak maka harus dicabut. ${ }^{25}$

Jimly Asshiddiqie memberikan pemaparan dalam bukunya yang berjudul "Perihal Undang-Undang” bahwa “Jika biasanya bentuk Peraturan Pemerintah adalah peraturan yang ditetapkan untuk menjalankan undang-undang sebagaimana mestinya, maka dalam keadaan kegentingan yang memaksa bentuk Peraturan Pemerintah itu dapat dipakai untuk menuangkan ketentuan-ketentuan yang semestinya dituangkan dalam bentuk undang-undang dan untuk menggantikan undang-undang." ${ }^{26}$ Lebih lanjut Jimly Asshiddiqie menyatakan bahwa pada dasarnya PERPPU itu sederajat atau memiliki kekuatan yang sama dengan UU. ${ }^{27}$

\footnotetext{
Id.

Jimly Asshiddiqie, Perihal Undang-Undang, Rajawali Pers, Jakarta, 2010, hlm., 55 Id.
} 
PERPPU disamakan kedudukannya dengan Undang-Undang menurut Maria Farida karena PERPPU itu peraturan pemerintah yang menggantikan undangundang, materi muatannya sama dengan materi muatan undang-undang. Hal senada juga disampaikan oleh Bagir Manan bahwa materi muatan PERPPU merupakan materi muatan Undang-Undang. Dalam keadaan biasa materi muatan tersebut harus diatur dengan Undang-Undang. ${ }^{28}$ Sebagaimana juga termaktub pada Pasal 11 UU No. 12 Tahun 2011 tentang Pembentukkan Peraturan Perundang-undangan yang berbunyi: "Materi muatan Peraturan Pemerintah Pengganti Undang-Undang sama dengan materi muatan Undang-Undang.”

Dari pemaparan di atas, dapat diambil benang merahnya bahwa kedudukan PERPPU itu sejajar dengan UU, sehingga muatan materinya pun sama dengan UU hanya saja dalam pembentukkannya yang berbeda yaitu dalam keadaan (hal-ikhwal) kegentingan memaksa. Selain daripada itu ketika dalam keadaan normal PERPPU tersebut harus dibahas kembali bersama DPR yang bisa jadi UU maupun ditolak kemudian dicabut untuk dinyatakan tidak berlaku.

Keadaan normal yang dimaksud sebenarnya berbicara mengenai pembatasan masa keberlakuan suatu PERPPU, sebagaimana termaktub dalam Pasal 22 ayat (2) UUD NRI 1945 disebutkan bahwa PERPPU setelah diterbitkan harus mendapatkan persetujuan DPR agar dapat menjadi Undang-Undang. Disebutkan bahwa "Peraturan pemerintah itu harus mendapat persetujuan Dewan Perwakilan rakyat dalam persidangan yang berikut". Ketentuan ini bukan saja mengatur mengenai syarat persetujuan DPR, namun juga menunjukkan bahwa PERPPU merupakan peraturan yang bersifat sementara, memiliki masa keberlakuan tertentu. Sehingga dapat dipahami bahwa parameter keadaan normal merupakan berkenaan dengan masa keberlakuan PERPPU tersebut.

Masa keberlakuan PERPPU menurut aturan konstitusi tersebut adalah sejak ditetapkan Presiden hingga pernyataan persetujuan DPR yang dilakukan pada "persidangan berikut". Penjelasan Pasal 52 ayat (1) Undang-Undang Nomor 12 Tahun 2011 tentang Pembentukan Peraturan Perundang-undangan

28 Ali Marwan Hsb, Pengujian Peraturan Pemerintah Pengganti Undang-Undang, Jurnal Legislasi Indonesia, Vol. 13, hlm, 145-152, 2016. 
menyatakan bahwa yang dimaksud dengan "persidangan yang berikut" adalah masa sidang pertama DPR setelah Peraturan Pemerintah Pengganti UndangUndang ditetapkan. Peraturan perundang-undang yang mengatur PERPPU di Indonesia tidak secara definitif mengatur masa keberlakuan Perppu. Pengaturan seperti ini berbeda dengan yang terdapat di salah satunegara Amerika Latin. Semisalnya Konstitusi di Negara Brazil 1988 menyebutkan bahwa dalam waktu 30 hari setelah diterbitkan PERPPU, parlemen harus menentukan sikap untuk menerima PERPPU itu yang berakibat menjadikannya undang-undang ataupun menolak yang berakibat tidak berlakunya PERPPU tersebut. Ketentuan yang terdapat pada Article 62 Konstitusi Brazil tersebut berbunyi:

"(1) Provisional measures lose their effectiveness as from the date of their issuance if they are not converted into law within a period of thirty days as from their publication, and Congress regulates the legal relations arising therefrom." 29

Urgensi mengatur masa berlaku PERPPU dengan waktu yang tegas adalah untuk memberikan batasan terhadap ihwal kegentingan yang memaksa sebagai syarat perppu. Semakin panjang atau semakin tidak tegas masa berlaku perppu berarti semakin panjang masa kegentingan dan kegentingan tersebut diatur oleh sebuah aturan sementara yang mengandung ketidakpastian. Selain itu, pembatasan ini juga untuk memberi ruang yang terbatas bagi kekuasaan eksekutif dalam membentuk aturan dari segi waktu. Bagaimanapun membentuk undangundang adalah kekuasaan legislatif, ketika kekuasaan tersebut dilakukan oleh lembaga lain dengan alasan situasi yang tidak normal maka harus mengandung berbagai pembatasan termasuk soal masa berlakunya. ${ }^{30}$

\section{Proses Pembentukkan dan Mekanisme Legislative Review Peraturan Pemerintah Pengganti Undang-Undang Dalam Perspektif Politik Hukum}

Kita ketahui bersama bahwa hukum dengan politik berjalan beriringan, sebagaimana dikemukakan oleh Mochtar Kusumaatmadja "politik dan hukum itu

29 Fitra Arsil, Menggagas Pembatasan Pembentukkan dan Materi Muatan PERPPU: Studi Perbandingan Pengaturan dan Penggunaan PERPPU di Negara-Negara Presidensial, Jurnal Hukum \& Pembangunan, ke-48, No. 1, 2018, hlm., 15-17

30 Id. 
interdeterminan, sebab politik tanpa hukum itu zalim, sedangkan hukum tanpa politik itu lumpuh. Akan tetapi Mahfud MD dalam hasil penelitiannya berpijak dari asumsi dan konsep tertentu bahwa "hukum merupakan produk politik", sebagai fakta sebenarnya bukan hanya hukum dalam arti UU yang merupakan produk politik, tetapi juga bisa mencakup hukum dalam arti-arti lain. ${ }^{31}$ Artinya, hukum adalah produk politik bukan saja UU tersebut, namun menyangkut semua jenis dan hierarki Peraturan Perundang-undangan sebagaimana yang hukum positif di Republik Indonesia.

Ahli Konstitusi terkemuka K.C. Wheare mengatakan sebagaimana dikutip oleh Moh. Mahfud MD, bahwa:

"Constitution, when they are framed and adopted, tend to reflect the dominant beliefs and interest, or some compromise between conflicting beliefs and interest, which are characteristic the society at the time....A constitution is indeed the resultant of parallelogram of forces-political, economic, and social-which operate at that time of its adoption. ${ }^{132}$

Moh. Mahfud MD memberikan penjelasan dari pernyataan K.C. Wheare bahwa tampak jelas Konstitusi (yang dalam artinya yang luas mencakup semua peraturan perundang-undangan dalam pengorganisasian negara) merupakan resultante (produk kesepakatan politik) sesuai dengan situasi politik, ekonomi, dan sosial pada saat dibuat jadi konfigurasi politik, sosial, ekonomi, dan budaya sangatlah berpengaruh atau menentukan produk konstitusi dan peraturan perundang-undangan. ${ }^{33}$

Di dalam bukunya, General Theory of Law and State, Hans Kelsen mengatakan bahwa satu keadaan politik yang menimbulkan pemerintah dan hukum baru dapat sah sebagai pemerintah dan konstitusi baru sejauh pemerintah tersebut secara politik bisa mempertahankan dan melakukannya. ${ }^{34}$

31 Moh. Mahfud MD, supra no. 4, hlm., 6

32 K.C. Wheare, "the modern Contitution", Oxford University Press, $3^{\text {rd }}$ Impression, London New York-Toronto, 1975, hlm 67. Sebagaimana dikutip dalam Bukunya Moh Mahfud MD, supra no. 31, hlm., 5

33 Id.

34 Id. 
Dari pemaparan di atas dapat dikatakan bahwa segala bentuk Peraturan Perundang-undangan merupakan hasil atau produk dari politik, bahkan dalam pembentukkan dan pengubahan maupun pencabutan suatu Peraturan Perundangundangan berada pada lembaga yang berwenang dalam posisi memiliki kekuasaan secara politik di pemerintahan. Begitu pula dalam pembahasan penelitian ini mengenai Peraturan Pemerintah Pengganti Undang-Undang.

Selama ini Undang-Undang selalu dibentuk oleh Presiden dengan persetujuan DPR, dan dalam keadaan normal, atau dibentuk oleh DPR dan disetujui bersama oleh DPR dan Presiden, serta disahkan oleh Presiden, sedangkan PERPPU dibentuk oleh Presiden tanpa persetujuan DPR karena adanya suatu "hal-ikhwal kegentingan yang memaksa." ${ }^{35}$ Proses pembentukan suatu peraturan Pemerintah Pengganti Undang-Undang (PERPPU) berjalan lebih singkat, mengingat pembentukanya dilakukan dalam hal ikhwal kegentingan yang memaksa. $^{36}$

Dalam pengertian "kegentingan yang memaksa" itu terkandung sifat darurat atau 'emergency' yang memberikan alas kewenangan kepada Presiden untuk menetapkan PERPPU atau disebut undang-undang darurat menurut Konstitusi RIS 1949 dan UUDS 1950, atau "emergency legislation" menurut ketentuan konstitusi di berbagai Negara lain. Pengertian bahaya itu dapat saja diartikan sebagai ancaman dari luar (ancaman eksternal) ataupun sebagai akibat tuntutan yang tak terelakkan dari dalam. Dari segi lain, "keadaan bahaya" yang datang dari luar itu dapat dilihat secara objektif fakta-fakta objektifnya, sehingga objektif atau tidaknya dinilai oleh Dewan Perwakilan Rakyat. Sedangkan "kegentingan yang memaksa" timbul dari penilaian subjektif Presiden belaka mengenai tuntutan mendesak dari dalam pemerintahannya untuk bertindak cepat dan tepat mengatasi keadaan yang genting. ${ }^{37}$

Sebagaimana pernyataan di atas memberikan pengertian bahwa frasa kegentingan yang memaksa merupakan syarat penting penetapan sebuah PERPPU

\footnotetext{
Maria Farida Indrati S., Ilmu Perundang-Undangan 2, Kanisius, Yogyakarta, 2007, hlm 80. Id.

Jimly Asshiddiqie, supra no. 26, hlm., 57
} 
oleh Presiden, batasan pemahaman terhadap frasa kegentingan yang memaksa diinterpretasikan berbagai macam bentuk penafsiran. Sebagai peraturan yang lahir bukan dalam kondisi normal, PERPPU di berbagai negara memang mensyaratkan situasi khusus sehingga presiden dapat melakukan pembentukan kebijakan secara mandiri dan proaktif. Di Brazil terdapat frasa "relevance and urgency" dan di Argentina terdapat frasa "exceptional circumtances" atau "necessity and urgency" sebagai syarat kondisi presiden dapat menerbitkan PERPPU. Frasa tersebut kira-kira dapat disejajarkan dengan frasa "hal ihwal kegentingan memaksa" di Indonesia. Dalam prakteknya penggunaan frasa tersebut sebagai penafsiran kondisi oleh presiden agar dapat diterbitkannya emergency decreerelatif sama permasalahannya di Indonesia. Peraturan perundangundangan tidak menyebut secara tegas syarat-syarat yang dikehendaki dari frasa tersebut. 38

Namun perlu digarisbawahi bahwa kegentingan yang memaksa merupakan hak subjektif Presiden, berdasarkan kualitas (baik secara kognitif maupun afektif) Presiden dapat mengeluarkan sebuah PERPPU. Hal ini berarti Presiden menganggap penerbitan sebuah PERPPU sebagai tanggapan terhadap kejadian luar biasa yang mengganggu stabilitas nasional yang segera membutuhkan tanggapan (kebijakan) di sini dan kini (hic et nunc). ${ }^{39}$ Penilaian subjektif Presiden tersebut harus didasarkan kepada keadaan objektif yaitu adanya tiga syarat sebagai parameter adanya kegentingan yang memaksa, dengan demikian PERPPU diperlukan apabila:

(1) Adanya keadaan, yaitu kebutuhan mendesak untuk menyelesaikan masalah hukum secara cepat berdasarkan Undang-Undang;

(2) Undang-Undang yang dibutuhkan tersebut belum ada sehingga terjadi kekosongan Undang-Undang, atau ada Undang-Undang tetapi tidak memadai;

\footnotetext{
38 Fitra Arsil, supra no. 29, hlm., 11

39 Hardyanto, Artikel Tesis, Judicial Review Peraturan Pemerintah Pengganti Undang-Undang ( Perppu ), Program Pascasarjana, Universitas Atma Jaya, Yogyakarta, 2014, hlm., 10-11
} 
(3) Kekosongan Undang-Undang tersebut tidak dapat diatasi dengan cara membuat Undang-Undang secara prosedur biasa karena akan memerlukan waktu yang cukup lama sedangkan keadaan yang mendesak tersebut perlu kepastian untuk diselesaikan. ${ }^{40}$

Adapun Proses Pembentukkan Peraturan Pemerintah Pengganti UndangUndang (PERPPU) ini di atur dalam ketentuan Peraturan Presiden No. 87 Tahun 2014 tentang Peraturan Pelaksanaan Undang-Undang No. 12 Tahun 2011 tentang Pembentukkan Peraturan Perundang-undangan. Tahapan Pembentukkan PERPPU adalah sebagai berikut: Pasal 57, "Dalam hal ikhwal kegentingan yang memaksa, Presiden menetapkan Peraturan Pemerintah Pengganti Undang-Undang.”

Pasal 58 (1) "Presiden menugaskan penyusunan Rancangan Peraturan Pemerintah Pengganti Undang-Undang kepada menteri yang tugas dan tanggung jawabnya sesuai dengan materi yang akan diatur dalam Peraturan Pemerintah Pengganti Undang-Undang tersebut sebagai Pemrakarsa"; (2) "Dalam penyusunan Rancangan Peraturan Pemerintah Pengganti Undang-Undang, menteri sebagaimana dimaksud pada ayat (1) berkoordinasi dengan Menteri dan menteri/pimpinan lembaga pemerintah non kementerian dan/atau pimpinan lembaga terkait."

Pasal 59 "Rancangan Peraturan Pemerintah Pengganti Undang-Undang yang telah selesai disusun disampaikan oleh menteri sebagaimana dimaksud dalam Pasal 58 ayat (1) kepada Presiden untuk ditetapkan."

Pasal 60 "Pemrakarsa menyusun Rancangan Undang-Undang tentang Penetapan Peraturan Pemerintah Pengganti Undang-Undang Menjadi UndangUndang setelah Peraturan Pemerintah Pengganti Undang-Undang ditetapkan oleh Presiden."

Pasal 61 (1) "Selain menyusun Rancangan Undang-Undang tentang Penetapan Peraturan Pemerintah Pengganti Undang-Undang Menjadi UndangUndang sebagaimana dimaksud dalam Pasal 60, Pemrakarsa juga menyusun Rancangan Undang-Undang tentang Pencabutan Peraturan Pemerintah Pengganti

40 R. Muhammad Mihradi, Kewenangan Mahkamah Konstitusi Menguji Peraturan Pemerintah Pengganti Undang-Undang/Perppu, Palar/Pakuan Law Review 3, no. 2: 1-15, 2017. 
Undang-Undang"; (2) "Rancangan Undang-Undang tentang Pencabutan Peraturan Pemerintah Pengganti Undang-Undang sebagaimana dimaksud pada ayat (1) memuat materi yang mengatur segala akibat hukum dari pencabutan Peraturan Pengganti Undang-Undang"; (3) "Dalam penyusunan Rancangan Undang-Undang tentang Penetapan Peraturan Pemerintah Pengganti UndangUndang Menjadi Undang-Undang dan Rancangan Undang-Undang tentang Pencabutan Peraturan Pemerintah Pengganti Undang-Undang sebagaimana dimaksud pada ayat (1), Pemrakarsa membentuk panitia antarkementerian dan/atau antarnonkementerian"; (4) "Hasil penyusunan Rancangan Undang-Undang sebagaimana dimaksud pada ayat (3) disampaikan kepada Menteri untuk dilakukan pengharmonisasian, pembulatan, dan pemantapan konsepsi"; (5) "Menteri menyampaikan kepada Pemrakarsa hasil pengharmonisasian, pembulatan, dan pemantapan konsepsi untuk disampaikan kepada Presiden."

Peraturan Pemerintah Pengganti Undang-Undang (PERPPU) yang telah melalui proses pembentukkannya dari penyusunan hingga penetapan sebagaimana disebutkan diatas, mulai berlaku sebagai norma hukum. PERPPU ini melahirkan norma hukum dan sebagai norma hukum baru akan dapat menimbulkan: (a) status hukum baru, (b) hubungan hukum baru, dan (c) akibat hukum baru. Norma hukum tersebut lahir sejak PERPPU disahkan dan memiliki kekuatan hukum mengikat sama halnya dengan UU. Nasib dari norma hukum tersebut tergantung kepada persetujuan DPR untuk menerima atau menolak norma hukum PERPPU tersebut. ${ }^{41}$

Disinilah Nampak sekali kebenaran Moh. Mahfud MD yang menyatakan bahwa hukum adalah produk politik, dimana adanya sebuah kegiatan legal policy garis (kebijakan) resmi tentang hukum yang akan diberlakukan baik dengan pembuatan hukum baru maupun dengan penggantian hukum lama, dalam rangka mencapai tujuan Negara. ${ }^{42}$ DPR sebagai lembaga legislatif berwenang menentukan persetujuan untuk menerima atau menolak sebuah norma hukum baru dari

41 Putusan MK Nomor: 138/PUU-VII/2009, hlm 20-21.
42 Moh. Mahfud MD, supra no. 32, hlm., 5 
PERPPU yang telah ditetapkan oleh Presiden, hal inilah yang disebut dengan Legislative Review.

Legislative Review adalah upaya ke lembaga legislatif atau lembaga lain yang memiliki kewenangan legislasi untuk mengubah suatu peraturan perundangundangan. Dalam legislative review, setiap orang bisa meminta agar lembaga legislasi melakukan revisi terhadap produk hukum yang dibuatnya dengan alasan, misalnya peraturan perundang-undangan itu sudah tidak sesuai lagi dengan perkembangan zaman, bertentangan dengan peraturan perundang-undangan yang lebih tinggi atau sederajat dengannya. ${ }^{43}$

Adapun mekanisme Legislative Review diatur dalam UU No. 12 Tahun 2011 tentang Pembentukkan Peraturan Perundang-undangan sebagai berikut, Pasal 52:

(1) Peraturan Pemerintah Pengganti Undang-Undang harus diajukan ke DPR dalam persidangan yang berikut.

(2) Pengajuan Peraturan Pemerintah Pengganti Undang-Undang sebagaimana dimaksud pada ayat (1) dilakukan dalam bentuk pengajuan Rancangan Undang-Undang tentang penetapan Peraturan Pemerintah Pengganti UndangUndang menjadi Undang-Undang.

(3) DPR hanya memberikan persetujuan atau tidak memberikan persetujuan terhadap Peraturan Pemerintah Pengganti Undang-Undang.

(4) Dalam hal Peraturan Pemerintah Pengganti Undang-Undang mendapat persetujuan DPR dalam rapat paripurna, Peraturan Pemerintah Pengganti Undang-Undang tersebut ditetapkan menjadi Undang-Undang.

(5) Dalam hal Peraturan Pemerintah Pengganti Undang-Undang tidak mendapat persetujuan DPR dalam rapat paripurna, Peraturan Pemerintah Pengganti Undang-Undang tersebut harus dicabut dan harus dinyatakan tidak berlaku.

(6) Dalam hal Peraturan Pemerintah Pengganti Undang-Undang harus dicabut dan harus dinyatakan tidak berlaku sebagaimana dimaksud pada ayat (5), DPR

43 Ali Salmande, 2011, Praktik Legislative Review Dan Judicial Review Di Indonesia, Hukum Online, https://www.hukumonline.com/klinik/detail/ulasan/cl1105/praktik-legislativereview--judicial-review-di republik-indonesia, diakses 20 Agustus, 2020. 
atau Presiden mengajukan Rancangan UndangUndang tentang Pencabutan Peraturan Pemerintah Pengganti Undang-Undang.

(7) Rancangan Undang-Undang tentang Pencabutan Peraturan Pemerintah Pengganti Undang-Undang sebagaimana dimaksud pada ayat (6) mengatur segala akibat hukum dari pencabutan Peraturan Pemerintah Pengganti Undang-Undang.

(8) Rancangan Undang-Undang tentang Pencabutan Peraturan Pemerintah Pengganti Undang-Undang sebagaimana dimaksud pada ayat (7) ditetapkan menjadi Undang-Undang tentang Pencabutan Peraturan Pemerintah Pengganti Undang-Undang dalam rapat paripurna yang sama sebagaimana dimaksud pada ayat (5).

Rancangan Undang-Undang tentang Penetapan PERPPU tersebut kemudian dibahas dengan mekanisme pembahasan yang sama dengan Rancangan UndangUndang yang berasal dari Pemerintah. ${ }^{44}$ Mekanisme pembahasan Rancangan Undang-Undang sesuai amanah UU No. 12 Tahun 2011 tentang Pembentukkan Peraturan Perundang-undangan yaitu sebagai berikut, Pasal 65:

(1) Pembahasan Rancangan Undang-Undang dilakukan oleh DPR bersama Presiden atau menteri yang ditugasi.

(2) Pembahasan Rancangan Undang-Undang sebagaimana dimaksud pada ayat (1) yang berkaitan dengan:
a. otonomi daerah;
b. hubungan pusat dan daerah;
c. pembentukan, pemekaran, dan penggabungan daerah;
d. pengelolaan sumber daya alam dan sumber daya ekonomi lainnya; dan
e. perimbangan keuangan pusat dan daerah,dilakukan dengan mengikutsertakan DPD.

\footnotetext{
44 Undang-Undang R.I No. 12 Tahun 2011, Pembentukkan Peraturan Perundang-undangan, L.N.R.I Tahun 2011 No. 82, Pasal 71 ayat (1).
} 
(3) Keikutsertaan DPD dalam pembahasan Rancangan Undang-Undang sebagaimana dimaksud pada ayat (2) dilakukan hanya pada pembicaraan tingkat I.

(4) Keikutsertaan DPD dalam pembahasan Rancangan Undang-Undang sebagaimana dimaksud pada ayat (2) dan ayat (3) diwakili oleh alat kelengkapan yang membidangi materi muatan Rancangan UndangUndang yang dibahas.

(5) DPD memberikan pertimbangan kepada DPR atas Rancangan UndangUndang tentang Anggaran Pendapatan dan Belanja Negara dan Rancangan Undang-Undang yang berkaitan dengan pajak, pendidikan, dan agama.

Pembahasan Rancangan Undang-Undang (RUU) tentang persetujuan PERPPU menjadi UU berlangsung antara DPR bersama Presiden berdasarkan Tata Tertib DPR. ${ }^{45}$ Hal ini berlangsung selama dua tingkat pembicaraan sesuai dengan amanat pasal-pasal di atas, yaitu pembicaraan tingkat I dalam rapat komisi, rapat badan legislasi (Baleg), ataupun Panitia Khusus (PANSUS). Sedangkan pembahasan tingkat II dalam rapat paripurna DPR. Pembicaraan tingkat I dilakukan urutan sebagai berikut:

a. Pembahasan tingkat I biasanya diawali dengan menyepakati jadwal pembahasan antara DPR dengan Pemerintah. Dan juga disepakati pula bahanbahan yang digunakan dalam proses pembahasan;

b. Setelah terjadi kesepakatan tentang jadwal dan bahan yang digunakan dalam proses pembahasan, maka setiap fraksi-fraksi di DPR diberikan kesempatan memberikan pandangan terhadap draf RUU serta proses yang akan digunakan dalam pembahasan RUU;

c. Pandangan fraksi-fraksi dan DPD jika RUU dalam lingkup wewenang DPD. Hal ini terlebih khusus terhadap RUU yang berasal dari Presiden seperti RUU tentang persetujuan PERPPU menjadi UU;

45 Peraturan DPR RI No. 1 Tahun 2014, tentang Tata Tertib, sebagaimana telah dirubah dengan Peraturan DPR RI No. 2 Tahun 2018, tentang Perubahan Ketiga Atas Peraturan DPR RI No. 1 Tahun 2014, tentang Tata Tertib, B.N.R.I. Tahun 2018 No. 1752, Pasal 131. 
d. Tanggapan Presiden atas pandangan fraksi atau tangapan pimpinan alat kelengkapan DPR atas pandangan Presiden. Biasanya jawaban yang disampaikan tidak final. Hal-hal yang masih belum mendapat tanggapan akan dibicarakan lebih lanjut dalam tingkat Panitia Kerja (PANJA);

e. Pembahasan RUU oleh DPR dan Presiden berdasarkan Daftar Inventaris Masalah (DIM). ${ }^{46}$

Dalam pembicaraan tingkat I dapat juga dilakukan: (a) rapat dengar pendapat umum (RDPU); (b) mengundang pimpinan lembaga Negara atau pimpinan lembaga lain yang terkait dengan materi RUU; (c) diadakan rapat interen. Setelah RDPU, anggota DPR akan menyusun dan kemudian membahas DIM untuk selanjutnya dibahas dalam tingkatan pembahasan PANJA. Komisi kemudian akan menyelenggarakan lagi sidang komisi dengan agenda utama adalah laporan hasil kerja dan pandangan fraksi-fraksi terhadap hasil kerja PANJA. Apabila dalam pandangan fraksi masih ada yang belum disetujui, maka biasanya akan diserahkan kembali ke PANJA untuk diselesaikan hingga waktu yang ditentukan, dan jika belum selesai juga maka hal-hal yang belum disepakati akan dibawa pada pembicaraan tingkat II dalam siding paripurna untuk diambil keputusan. $^{47}$

Setelah komisi, Baleg, panitia anggaran atau panitia khusus yang ditunjuk selesai melakukan pembicaraan tingkat I dengan materi yang mewakili Presiden maka tahapan berikutnya dalam pembahasan RUU persetujuan PERPPU menjadi UU adalah pembicaraan tingkat II. Pembicaraan tingkat II dilakukan dengan didahului penyampaian laporan yang berisi proses, pendapat mini fraksi, pendapat mini DPD (jika terkait kewenangan DPD), dan hasil pembicaraan tingkat I. Setelah itu dilanjutkan dengan pernyataan persetujuan atau penolakan dari tiaptiap fraksi dan anggota secara lisan yang diminta oleh pimpinan rapat paripurna DPR, lalu pembacaan oleh menteri yang mewakilinya. ${ }^{48}$

\footnotetext{
Sirajuddin, dkk, supra no. 23, hlm., 156-157

Id.

48 Peraturan DPR RI No. 1 Tahun 2014, tentang Tata Tertib, sebagaimana telah dirubah dengan Peraturan DPR RI No. 2 Tahun 2018, tentang Perubahan Ketiga Atas Peraturan DPR RI No. 1 Tahun 2014, tentang Tata Tertib, B.N.R.I. Tahun 2018 No. 1752, Pasal 152 ayat (1).
} 
Pada tahapan pembicaraan tingkat II Rancangan Undang-Undang tentang penetapan PERPPU menjadi UU kemudian diambil persetujuan. Rapat paripurna DPR akan memutuskan menolak atau menyetujui PERPPU tersebut untuk menjadi UU. Persetujuan diambil dengan mengutamakan musyawarah mufakat dan apabila tidak mencapai kata sepakat maka akan dilakukan mekanisme pengambilan keputusan dengan suara terbanyak. ${ }^{49}$ Selama proses pembahasan Rancangan Undang-Undang tentang penetapan PERPPU menjadi UU diadakan di Dewan Perwakilan Rakyat, maka PERPPU tersebut dinyatakan tetap mempunyai daya laku dan tetap mengikat umum sebagai Peraturan Pemerintah Pengganti UndangUndang, sampai suatu saat ia dinyatakan ditolak atau disetujui oleh Dewan Perwakilan Rakyat menjadi suatu Undang-Undang. Apabila Rancangan UndangUndang yang berasal dari Peraturan Pemerintah Pengganti Undang-Undang tersebut disetujui oleh Dewan Perwakilan Rakyat, maka akan menjadi UndangUndang, sedangkan apabila ditolak oleh Dewan Perwakilan Rakyat, maka Peraturan Pemerintah Pengganti Undang-Undang tersebut harus dicabut dan dinyatakan tidak berlaku. ${ }^{50}$

Sesuai dengan ketentuan Pasal 52 UU No. 12 Tahun 2011, dalam hal PERPPU yang tidak mendapat persetujuan DPR harus dicabut dan harus dinyatakan tidak berlaku, maka Presiden atau DPR mengajukan Rancangan Undang-Undang tentang pencabutan PERPPU tersebut. Rancangan UndangUndang tentang pencabutan PERPPU mengatur segala akibat hukum dari pencabutan Peraturan Pemerintah Pengganti Undang-Undang. Rancangan Undang-Undang tentang pencabutan Peraturan Pemerintah Pengganti UndangUndang ditetapkan menjadi Undang-Undang tentang pencabutan Peraturan Pemerintah Pengganti Undang-Undang dalam rapat paripurna yang sama sebagaimana rapat paripurna untuk mendapat persetujuan DPR. ${ }^{51}$

49 Peraturan DPR RI No. 1 Tahun 2014, tentang Tata Tertib, sebagaimana telah dirubah dengan Peraturan DPR RI No. 2 Tahun 2018, tentang Perubahan Ketiga Atas Peraturan DPR RI No. 1 Tahun 2014, tentang Tata Tertib, B.N.R.I. Tahun 2018 No. 1752, Pasal 152 ayat (2).

$50 \quad$ Maria Farida Indrati S., supra no. 35, hlm., 85

51 Undang-Undang R.I No. 12 Tahun 2011, tentang Pembentukkan Peraturan Perundangundangan, L.N.R.I Tahun 2011 No. 82, Pasal 52. 
Pembahasan Rancangan Undang-Undang tentang pencabutan Peraturan Pemerintah Pengganti Undang-Undang dilaksanakan melalui mekanisme khusus yang dikecualikan dari mekanisme pembahasan Rancangan Undang-Undang. Ketentuan mengenai mekanisme khusus tersebut dilaksanakan dengan tata cara sebagai berikut:

a) Rancangan Undang-Undang tentang pencabutan Peraturan Pemerintah Pengganti Undang-Undang diajukan oleh DPR atau Presiden;

b) Rancangan Undang-Undang tentang pencabutan sebagaimana dimaksud dalam huruf (a) diajukan pada saat rapat paripurna DPR tidak memberikan persetujuan atas Peraturan Pemerintah Pengganti Undang-Undang yang diajukan oleh Presiden; dan

c) Pengambilan keputusan persetujuan terhadap Rancangan Undang-Undang tentang pencabutan sebagaimana dimaksud dalam huruf (b) dilaksanakan dalam rapat paripurna DPR yang sama dengan rapat paripurna penetapan tidak memberikan persetujuan atas Peraturan Pemerintah Pengganti UndangUndang tersebut. ${ }^{52}$

Dari pemaparan di atas, inilah mekanisme sebuah Legislative Review atau biasa disebut dengan Political Review oleh lembaga Legislatif yaitu Dewan Perwakilan Rakyat atau lembaga yang memiliki kewenangan legislasi. Hal ini pula dalam perspektif politik hukum memberikan sebuah gambaran betapa jelasnya perpolitikan hukum dalam menciptakan hukum baru maupun menggantikan hukum lama sebagai upaya mewujudkan tujuan Negara Republik Indonesia.

\section{Penutup}

Legislative Review merupakan sebuah upaya me-review kembali yang dilakukan oleh lembaga legislatif atau lembaga lain yang memiliki kewenangan legislasi untuk mengubah suatu peraturan perundang-undangan. Dalam legislative review, setiap orang bisa meminta agar lembaga legislasi melakukan revisi terhadap produk hukum yang dibuatnya dengan alasan, misalnya peraturan

52 Undang-Undang R.I. No.12 Tahun 2011 tentang Pembentukkan Peraturan Perundangundangan, L.N.R.I Tahun 2011 No. 82, Pasal 71 ayat (2) dan ayat (3). 
perundang-undangan itu sudah tidak sesuai lagi dengan perkembangan zaman, bertentangan dengan peraturan perundang-undangan yang lebih tinggi atau sederajat dengannya.

Berkenaan dengan terbitnya Peraturan Pemerintah Pengganti UndangUndang (PERPPU) akibat adanya hal-ikhwal kegentingan yang memaksa, sehingga pemerintah harus segera cepat dan tepat memberikan legal policy (kebijakan) dalam bentuk norma hukum untuk mengatasi kegentingan yang memaksa tersebut yang pada kesempatan ini norma hukum tersebut adalah Peraturan Pemerintah Pengganti Undang-Undang (PERPPU) yang dimana proses pembentukannya pun berjalan lebih singkat, mengingat pembentukanya dilakukan dalam hal ikhwal kegentingan yang memaksa.

Akan tetapi ketika keadaan sudah kembali normal, maka Peraturan Pemerintah Pengganti Undang-Undang tersebut harus diajukan kepada DPR dalam bentuk Rancangan Undang-Undang (RUU) tentang Penetapan Peraturan Pemerintah Pengganti Undang-Undang menjadi Undang-Undang, kemudian dibahas dan ditetapkan untuk setujui maupun ditolak menjadi Undang-Undang. Inilah yang disebut dengan Legislative Review (Political Review).

Dalam perspektif politik hukum tentu sebuah pembentukkan norma hukum merupakan resultante (produk kesepakatan politik) sesuai dengan situasi politik, ekonomi, dan sosial pada saat dibuat jadi konfigurasi politik, sosial, ekonomi, dan budaya sangatlah berpengaruh atau menentukan produk konstitusi dan peraturan perundang-undangan salah satunya yakni Peraturan Pemerintah Pengganti Undang-Undang. Sehingga dalam proses Legislative Review bisa jadi PERPPU tersebut disetujui menjadi UU maupun ditolak untuk dicabut dan dinyatakan tidak berlaku.

Peraturan Pemerintah Pengganti Undang-Undang (PERPPU) bukanlah Undang-Undang selagi bernama PERPPU maka pengujiannya tidak dapat disamakan dengan Undang-Undang, kecuali jika PERPPU tersebut telah disidangkan oleh DPR dan mendapat persetujuan menjadi Undang-Undang melalui mekanisme Legislative Review. Ketika Peraturan Pemerintah Pengganti Undang-Undang (PERPPU) dinyatakan disetujui menjadi Undang-Undang, maka 
pengujian Undang-Undang terhadap Undang-Undang Dasar Negara Republik Indonesia Tahun 1945 bisa dilakukan melalui Judicial Review ke Mahkamah Konstitusi. Sehingga penulis menyatakan bahwa selama norma hukum berbentuk Peraturan Pemerintah Pengganti Undang-Undang (PERPPU) pengujiannya terlebih dahulu harus melalui Legislative Review yang memiliki kewenangan di bidang legislasi yaitu Dewan Perwakilan Rakyat Republik Indonesia.

\section{Daftar Pustaka}

Buku:

Achmad Ali, Menguak Teori Hukum (Legal Theory) Dan Teori Peradilan (Uudicialprudence): Termasuk Interpretasi Undang-Undang (Legisprudence), Kencana, Jakarta, 2017

Ani Purwati, Metode Penelitian Hukum Teori Dan Praktek, Edited by Tika Lestari, Jakad Media Publishing, Surabaya, 2020

Fitra Arsil, Menggagas Pembatasan Pembentukkan dan Materi Muatan PERPPU: Studi Perbandingan Pengaturan dan Penggunaan PERPPU di NegaraNegara Presidensial, Jurnal Hukum \& Pembangunan, ke-48, No. 1, 2018

I Made Pasek Dhianta, Metode Penelitian Hukum Normatif; Dalam Justifikasi Teori Hukum, Kencana, Jakarta, 2016

I Dewa Gede Atmadja dan I Nyoman Putu Budiartha, Teori-Teori Hukum, Setara Press, Malang, 2018

I Gde Pantja Astawa, Dinamika Hukum dan Ilmu Perundang-undangan di Indonesia, PT Alumni, Bandung, 2008

Jimly Asshiddiqie, Perihal Undang-Undang, Rajawali Pers, Jakarta, 2010

Jonaedi Efendi dan Johnny Ibrahim, Metode Penelitian Hukum Normatif Dan Empiris, Prenadamedia Group, Depok, 2018

Maria Farida Indrati S, Ilmu Perundang-Undangan 1, Kanisius, Yogyakarta, 2007

Maria Farida Indrati S, Ilmu Perundang-Undangan 2, Kanisius, Yogyakarta, 2007

Munir Fuady, Teori-Teori Besar (Grand Theory) Dalam Hukum, Kencana, Jakarta, 2014

Moh. Mahfud MD, Politik Hukum Di Indonesia, Rajawali Press, Jakarta, 2011

Ni'matul Huda, Dinamika Ketatanegaraan Indonesia Dalam Putusan MK. FH UII Press, Yogyakarta, 2011

Peter Mahmud Marzuki, Penelitian Hukum, Kencana, Jakarta, 2017 
Sirajuddin, Fatkhurohman, dan Zulkarnain, Legislative Drafting: Pelembagaan Metode Partisipatif Dalam Pembentukan Peraturan Perundang-Undangan, Setara Press, Malang, 2016

\section{Jurnal:}

Ali Marwan Hsb, Pengujian Peraturan Pemerintah Pengganti Undang-Undang, Jurnal Legislasi Indonesia, Vol 13, hlm 145-152, 2016

Erlangga Hamid Putra Zakaria, Legislative Review Dewan Perwakilan Rakyat Terhadap Peraturan Pemerintah Pengganti Undang-Undang, Vol VII No. 1, LEX ADMINISTRATUM, hlm 62-63, 2019

Hardyanto, Artikel Tesis, Judicial Review Peraturan Pemerintah Pengganti Undang-Undang ( Perppu ), Oleh Program Pascasarjana, Universitas Atma Jaya, Yogyakarta, 2014

R. Muhammad Mihradi, Kewenangan Mahkamah Konstitusi Menguji Peraturan Pemerintah Pengganti Undang-Undang/Perppu, Palar/Pakuan Law Review 3, no. 2: 1-15, 2017

\section{Internet:}

Ali Safa'at, "Toetsingsrecht Van De Rechter," Hukum Acara Pengujian Undang Undang Terhadap Undang-Undang Dasar, hlm 82-148, 2006, http://safaat.lecture.ub.ac.id/files/2011/11/BAB-V PUU.pdf, diakses 20 Agusutus, 2020

Ali Salmande, Praktik Legislative Review Dan Judicial Review Di Indonesia, Hukum Online, 2011,

https://www.hukumonline.com/klinik/detail/ulasan/cl1105/praktik

legislative-review--judicial-review-di-republik-indonesia, diakses 20

Agustus, 2020

\section{Peraturan Perundang-undangan:}

Undang-Undang Dasar Negara Republik Indonesia Tahun 1945

Undang-Undang RI No. 12 Tahun 2011 tentang Pembentukkan Peraturan Perundang-undangan Lembaran Negara Republik Indonesia Tahun 2011 Nomor 82. Sebagaimana telah diubah dengan UU RI No. 15 Tahun 2019 tentang Perubahan Atas UU RI No. 12 Tahun 2011 tentang Pembentukkan Peraturan Perundang-undangan Lembaran Negara Republik Indonesia Tahun 2019 Nomor 183.

Peraturan DPR RI No. 1 Tahun 2014, tentang Tata Tertib, sebagaimana telah diubah dengan Peraturan DPR RI No. 2 Tahun 2018, tentang Perubahan Ketiga Atas Peraturan DPR RI No. 1 Tahun 2014, tentang Tata Tertib, B.N.R.I. Tahun 2018 No. 1752.

Putusan MK Nomor: 138/PUU-VII/2009 